UDC $579.66: 621.891$

\title{
NANOPARTICLES CONTAINING TUNGSTEN AND MOLYBDENUM IN MICROBIAL BIOFILMS
}

\author{
V.G. LAZARIEV ${ }^{1}$, V.F. LABUNETS ${ }^{1}$, M.A. BORETSKA ${ }^{2}$, \\ L.G. ASAULENKO ${ }^{2}$, I.A. KOZLOVA ${ }^{2}$ \\ 1 National aviation university, Kyiv, \\ 2 Zabolotny Institute of Microbiology and Virology NASU, Kyiv
}

Article discusses examples of experiments devoted to biotechnology of metals. Nanosized particles of Mo and W were obtained and observed.

Keywords: Sulfur cycle bacteria, biofilm, nanoparticles, molybdenum, tungsten, exopolymer substance.

Taking into attention global trend of biotechnology role increasing on the background of traditional chemical industries [1, 2], we just following in the footsteps searching for new applications of microbial technology. Last decades this direction of industry development leaving actual. So, authors have researched the perspectivies of sulfur cycle bacteria using for materials surface treatment $[3,8,9]$.

Systematic studies of microbial biofilms [4] have shown that the formation of biofilms increases the intensity of chemical reactions on the surface. This may accelerate the dissolution of substrate and mineralization processes.

Mineral components of the biofilm with exopolymer substance and attached cells can remain on the surface of the solid phase of substrate after detachment, and after drying the sample. In some cases, we observed the biofilm formed by sulphatereducing bacteria which were difficult to remove from the surface [9]. However, adhesion to the surface of biofilm was not critical in the present study. 
The main task of the study was to determine the ability of biofilms formed by bacteria of the sulfur cycle to accumulate heavy transition metals in the form of nanoparticles.

Nanoparticles produced by bacteria nowadays are commonplace example of the biological technologies preparations of gold and silver, polymers and other chemical compounds already present as a product on market [4].

Molybdenum and tungsten in the form of alloys and their compounds are widely used in engineering. However being expensive materials they are applied more often as coatings, additives, alloying elements etc. Accordingly to [4], Mo is known as metal that can exist in the form of nanopowders and nanostructured metal colloids.

In this experiment, the biofilm formed by soil bacteria: sulphate-reducing, thionic and its heterotrophic satellites. Chemical activity of that bacteria and particularly in biofilm forming communities is well known as a corrosion factor [6].

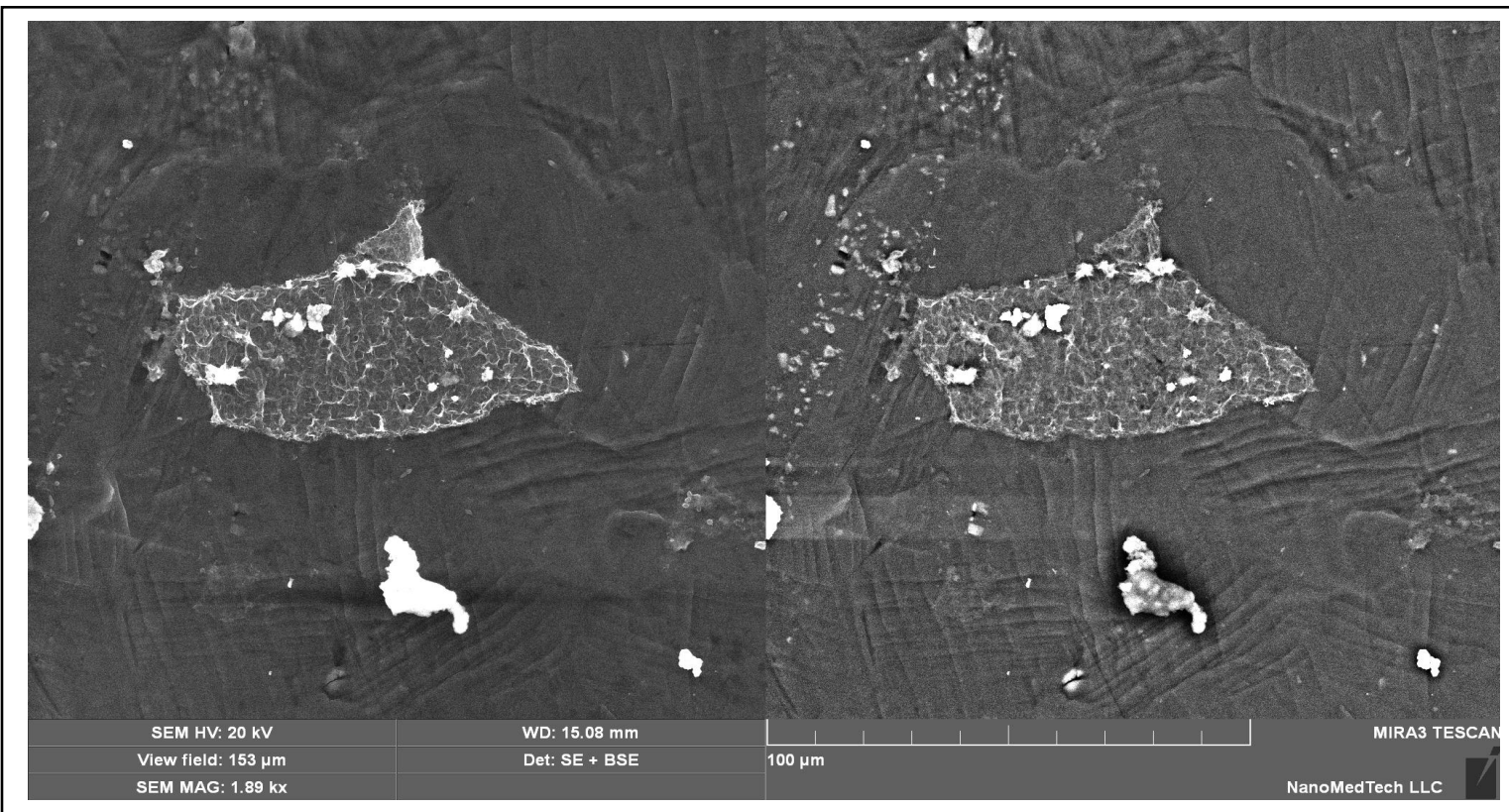

Fig. 1. Piece of exopolymer matrix of Sulfate reducing bacteria

Biofilms were cultivated in liquid nutrient media on the surface of aircraft aluminum-based alloys, titanium alloys and glass. Tungsten and molybdenum compounds solutions applied on the biofilms surfaces, after extracting of the sample at the end of the exposure. As it mentioned in [11] biofilm less sensitive to chemical 


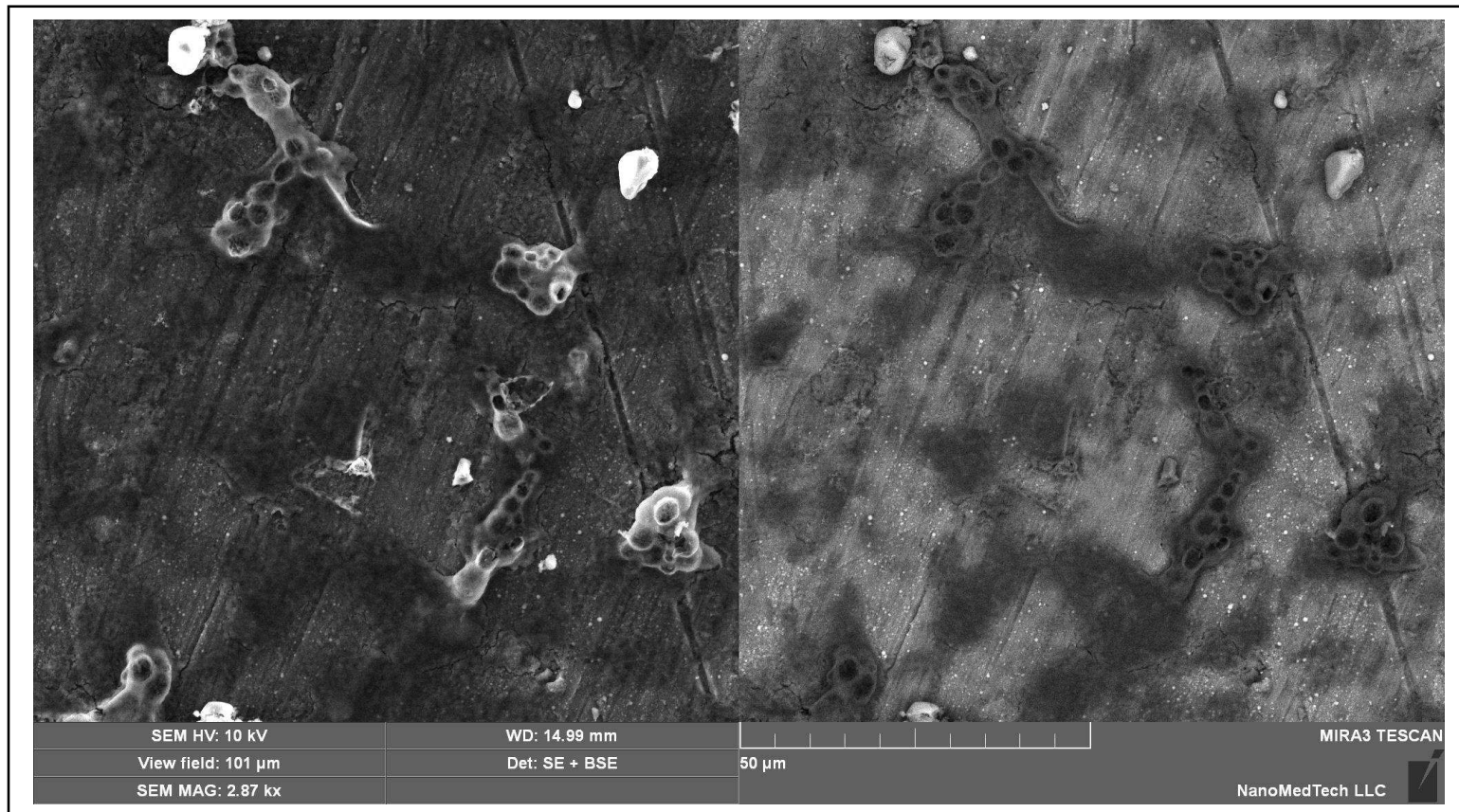

Fig. 1. Aluminium sample surface after exposition with tionic bacteria

agents than planctonic cells. Established biofilm can survive the treatment with antimicrobial substance.

After processing the samples were examined using the field emission scanning electron microscope Tescan Mira3 equipped with INCA 80 microanalysis system.

All biofilms in our experiments were based on exopolymer matrix. That polymer structures are cowering more solid substrate surface than cells attached do (fig. $1-3$ ).

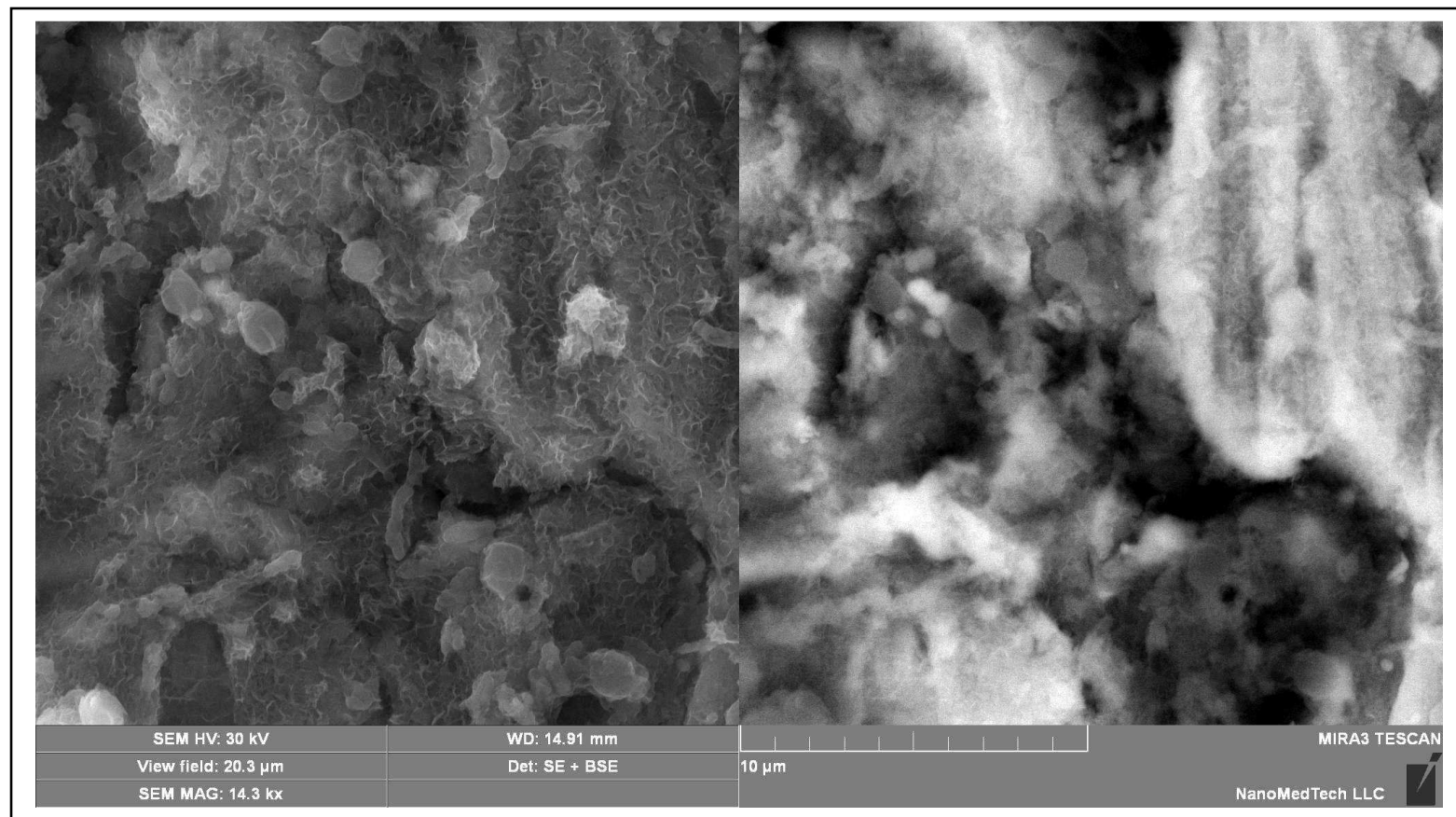

Fig. 2. Sulfate reducing bacteria on biopolymer 


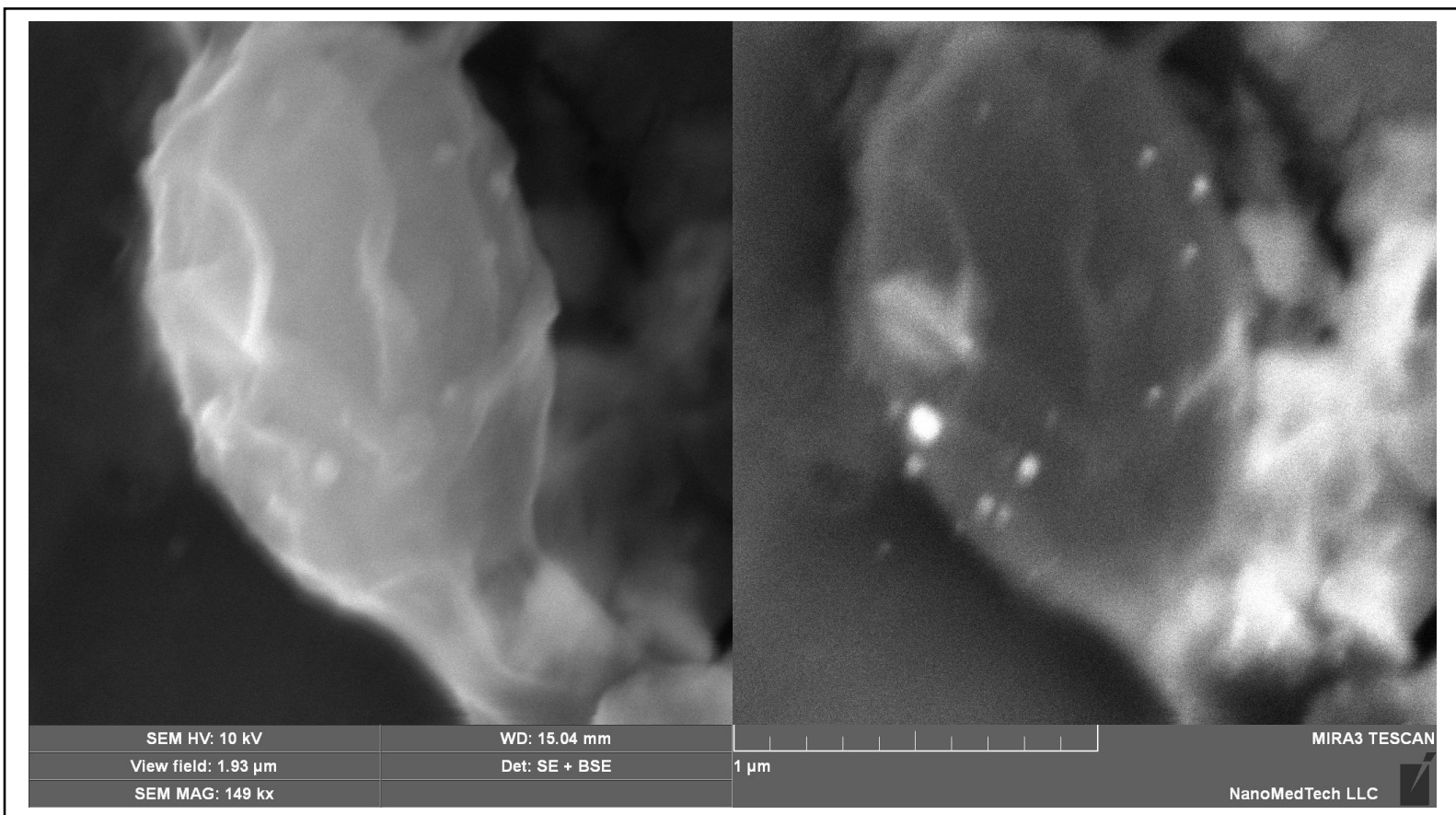

Fig. 3. Sulfate reducing bacterial cell with Mo nanoparticles

On figure 4 bacterial cell with Mo nanoparticles is shown. Having a higher atomic number, these objects are better seen on BSE micrograph (right image).

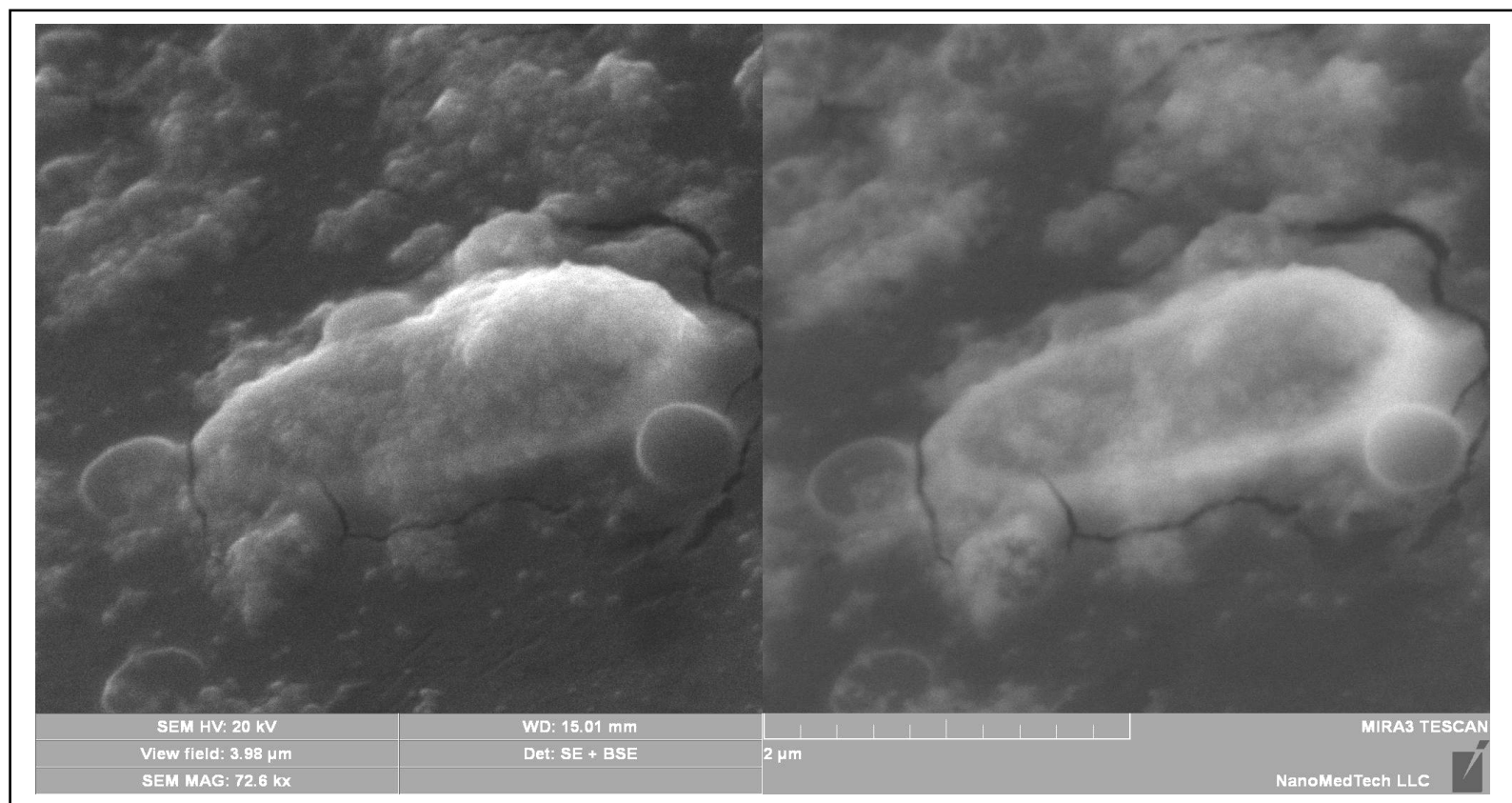

Fig. 4. Sulfate reducing bacteria with exopolymer and W nanoparticles on it 
Tungsten nanoparticles we observed on the exopolymer surface only. After removing EPS cowered with W particles bacterial cell leaving enriched with metal and it seen on BSE pictures (fig. 5, 6)

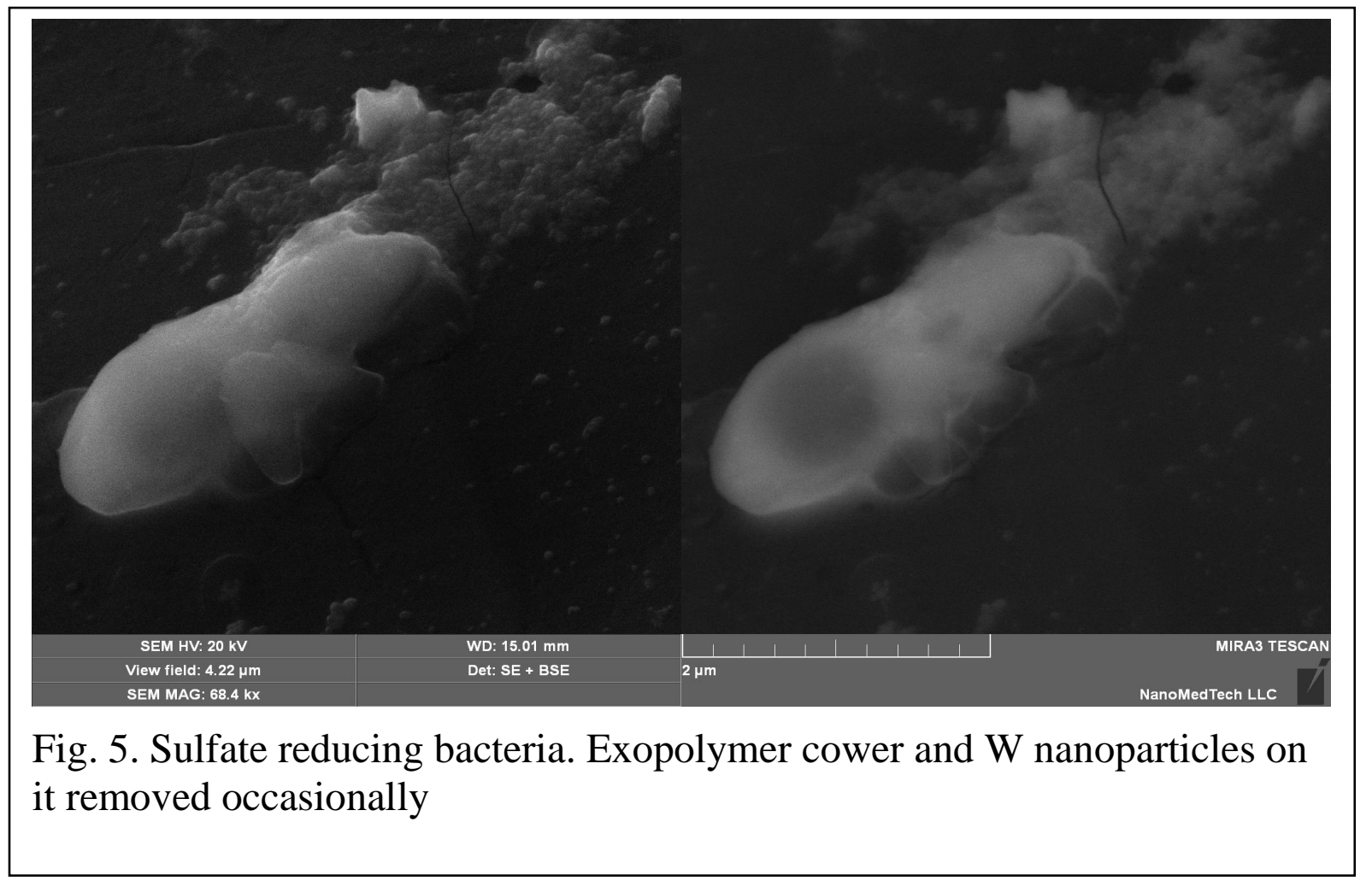

A result succeeded in obtaining the nanoparticles containing tungsten and molybdenum on the surface of bacterial cells (fig. 4), and in the exopolymer substance.

Analytical considerations taking to attention spectral interference of S- $K$ - and Mo- $L$-series, however, analysis by these taken interfered lines we preferred because of higher intensity and resolution at the energy $2-3 \mathrm{keV}$. As it seen on fig. 7 spectral lines of $\mathrm{S}$ and Mo interfering with continuous background maximum. To exclude mistakes we have identified molybdenum by $K$-x-ray series (at $\mathrm{HV} 30 \mathrm{kV}$ and resolution $1 \mathrm{~nm}$ - requirements we did searching for instrument by).

The studies suggest the possibility of microbial biofilms applying in the "green" technology. It may also be of interest the molybdenum and tungsten biosorption by soil bacteria. 


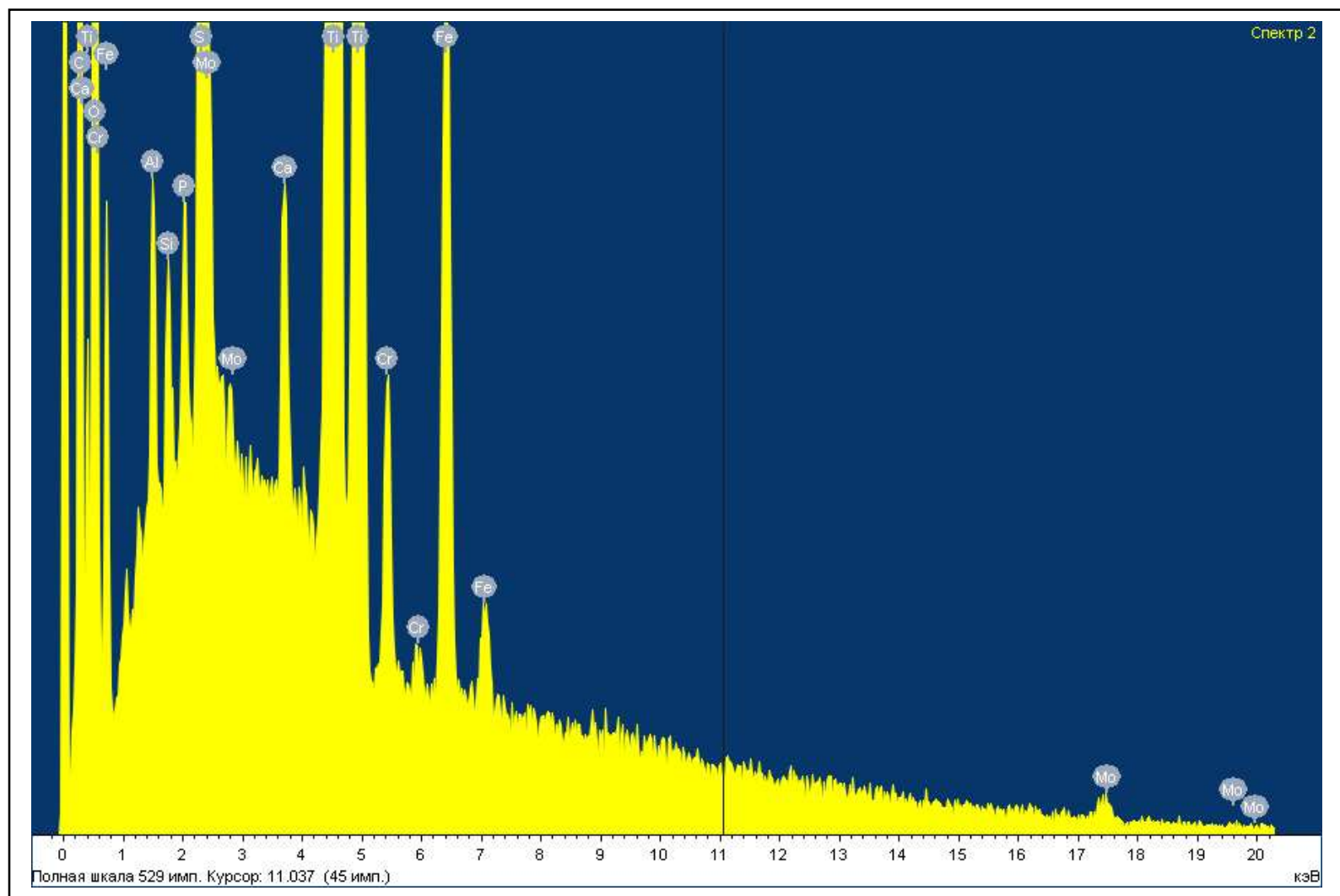

Fig. 6. Molybdenum $K$-line presense in case of S- $K$ and Mo- $L$ series spectral interference

We have observed and identified nanoparticles of sizes from 10 and less up to $100 \mathrm{~nm}$. Particles were attached to cells and in other case cowered exopolymer matrix. Most presentable results have shown sulfate-reducing bacteria, but other bacteria of sulfur cycle - tionic and their heterotrophic satellites - Pseudomonas forming common biofilms in nature they can play the role in biofilm chemical activity changing and control.

Observed particles were identified as containing Mo or W and S but correct analysis will be possible after separation of sufficient quantities of such particles.

\section{REFERENCES}

1. Gavrilescu M. Biotechnology - a sustainable alternative for chemical industry / M. Gavrilescu, Y. Chisti // Biotechnology Advances. - 2005. - №23. - P. $471-499$. 
2. Shimizu H. Metabolic Engineering - Integrating Methodologies of Molecular Breeding and Bioprocess Systems Engineering / Hiroshi Shimizu // Journal of Bioscience and Bioengineering. - 2002. - Vol. 94, No. 6. - P. 563-573.

3. Микробная модификация поверхности материалов. / А.П. Кудрин, В.Ф. Лабунец, В.Г. Лазарев и др. // Восточно-Европейский журнал передових технологий. - 2005. - № 5 (17). - С. 68-75.

4. Microbial biofilms / [ed. by H.M. Lappin-Scott, J.W. Costerton]. Cambridge.: University Press. - 1995. - 324 p.

5. Singh S.K. Metallic nanoparticles: biological perspective / S.K. Singh, S. Shrivastava, D. Dash. // Metal Nanoparticles in Microbiology / [Ed. By Mahendra Rai, Nelson Duran]. - Berlin: Springer-Verlag Heidelberg, 2011. - 303 p.

6. Минералообразование на поверхности малоуглеродистой стали в процесс ее коррозии / [Белевцев Р.Я., Козлова И.А., Спивак С.Д. и др.]. // Збірник статей III Міжнародної науково-практичної конференції „Екологічна безпека: проблеми і шляхи вирішення”, 10-14 вересня 2007 р. - том 1. - Харків: Райдер, 2007. - С. 22-27.

7. О новых технологиях модификации трибосистем с уменьшением трения на поверхности авиационных сплавов при биоминералообразовании / [Белевцев Р.Я., Спивак С.Д., Соботович Э.В. и др.] // Збірник статей Міжнародної науково-практичної конференції „Екологічна безпека: проблеми $\mathrm{i}$ шляхи вирішення”. - том 11. - Харків: Райдер, 2012. - С. 212-216.

8. Biotechnology perspectives in surface engineering. Review. / [V.F. Labunets, V.G. Lazariev, R.J. Belevtsev et al.] // Proceedings of the 5-th World congress "Aviation in the XXI-st century" - "Safety in Aviation and Space Technologies", September 25-27, 2012. - Vol. 2. - K.: NAU, 2012. - P. 4.1.26 4.1.29.

9. Нові підходи щодо використання біотехнології для поверхневої обробки авіаційних сплавів / [В.Ф.Лабунець, В.Г.Лазарєв , Е.Вайс та ін.] // Матеріали міжнародної науково-технічної конференції АВіА-2013, 21-23 травня 2013, К.: НАУ. - С. (в друку) 
10. Bacteriogenic products using for increasing performance capabilities of the detonating coatings / [V. Labunets, V. Lazariev, E. Korbut et al.] // Proceedings of the 4-th World congress "Aiation in the XXI-st century" - "Safety in Aviation and Space Technologies", Sep. 2010. - Vol. 1. - K.: NAU, 2010. - P. 13.55-13.58.

11. Schulte S. Efficacy of biocides against biofilms / S. Schulte, J. Wingender, H.C. Flemming // Directory of Microbicides for the Protection of Materials. A handbook / [Ed. Wilfried Paulus]. - Dordrecht, The Netherlands: Springer, 2004. -787 p.

\title{
НАНОЧАСТИЦЫ, СОДЕРЖАЩИЕ ВОЛЬФРАМ И МОЛИБДЕН В МИКРОБНЫХ БИОПЛЕНКАХ
}

\author{
В.Г. ЛАЗАРЕВ ${ }^{l}$ В.Ф. ЛАБУНЕЦ', М.А. БОРЕЦКАЯ \\ Л.Г. АСАУЛЕНКО, И.А. КОЗЛОВА \\ ${ }^{1}$ Национальный авиационный университет, г. Киев, \\ ${ }^{2}$ Институт микробиологии и вирусологии им. Д.К. Заболотного НАН \\ Украины, г. Киев \\ В статье рассматриваются примеры экспериментов, посвященных \\ биотехнологии металлов. Получены и исследованы наноразмерные частиць
} Mo $u W$.

Ключевые слова: бактерии цикла серы, биопленка, наночастицы, молибден, вольфрам, экзополимер. 


\title{
НАНОЧАСТИНКИ, ЩО МІСТЯТЬ ВОЛЬФРАМ І МОЛІБДЕН В МІКРОБНИХ БІОПЛІВКАХ
}

\author{
В.Г. ЛАЗАРСВ ${ }^{1}$ В.Ф. ЛАБУНЕЦЬ ${ }^{1}$ М.О. БОРЕЦКА \\ Л.Г. АСАУЛЕНКО ${ }^{2}$ І.А. КОЗЛОВА \\ ${ }^{1}$ Начіональний авіаційний університет, м. Київ, \\ ${ }^{2}$ Інститут мікробіології і вірусології ім. Д.К. Заболотного НАН України, \\ м. Київ \\ У статті розглядаються приклади експериментів, присвячених
} біотехнології металів. Отримано і досліджено нанорозмірні частинки Мо i W.

Ключові слова: бактерії циклу сірки, біоплівка, наночастинки, молібден, вольфрам, екзополімер. 